\title{
DEVELOPMENT OF CREATIVITY AND IMAGINATION OF SCHOOLCHILDREN IN FINE ARTS CLASSES
}

\section{Botir Boltabaevich Baymetov}

Professor Chirchik State Pedagogical Institute

\section{Laylo Misoatova}

Student Chirchik State Pedagogical Institute

\section{ABSTRACT}

The article describes how visual activity contributes to the development of abstract thinking and specific, sensory experiences in schoolchildren, and in the process of the image, the child selects from the integral visual image proportions, color, silhouette, line as general and constant characteristics of the reality visually perceived by it.

KEYWORDS:- Visual activity, creativity, perception, color, spirituality.

\section{INTRODUCTION}

Recently, in Uzbekistan, special attention has been paid to improving the quality of education based on modern requirements, updating the curricula of secondary schools, educational and methodological literature in accordance with international requirements, introducing advanced pedagogical and information technologies in the educational process. In particular, in the Decree of the President of the Republic of Uzbekistan PF-5712 of April 29, 2019 "On the concept of development of the public education system until 2030", the improvement of teaching methods, the gradual introduction of the principles of individualization into the educational process is determined; the formation of a strong motivation for learning among students, the development of teaching and assessment methods based on a competencebased approach, critical thinking, independent search for information, the development of analytical and other skills.

The Strategy of Actions for the Further Development of the Republic of Uzbekistan defines such tasks as "Stimulating research and innovation activities, creating effective mechanisms for the implementation of scientific and innovative achievements", the positive direction of the implementation of this goal and the tasks set shows that to ensure the spiritual development of the country, first of all, it is important to provide the younger generation with scientific knowledge, develop their spiritual 
CURRENT RESEARCH JOURNAL OF PHILOLOGICAL SCIENCES 2(5): 55-61,

May 2021 DOI: https://doi.org/10.37547/philological-crjps-02-05-14

ISSN 2767-3758

(C)2021 Master Journals

\section{Crossref do) 81 Google}

Accepted25 $5^{\text {th }}$ May, 2021 \& Published 31 $1^{\text {th }}$ May, 2021

thinking, intellectual potential and spiritual and moral qualities.

\section{THE MAIN FINDINGS AND RESULTS}

It is known that the fine arts is one of the means of developing the creative imagination, increasing the intellectual potential and spiritual and moral quality of schoolchildren. The program of teaching fine arts in schools in Uzbekistan includes such types of lessons as thematic drawing, drawing from life, decorative drawing. These types of lessons very actively contribute to the development of students' imagination.

Decorative painting mainly develops the reproductive imagination, as children usually study various types of folk paintings in the classroom. But still, there are tasks that require creative imagination (for example, application, drawing an ornament, etc.).

Thematic drawing, in our opinion, most of all contributes to the development of creative imagination. In thematic drawing, the child shows both artistic and creative abilities. And here, first of all, it is necessary to define the concept of the topic itself. No matter what kind of visual activity the child is engaged in, there will always be an interest in creativity and there will always be originality. This, in turn, requires novelty, a bold look, the ability to see familiar things from different angles, and the presentation of different possibilities and combinations. Creativity and imagination are always close by. There is no creativity without imagination.

Painting activities have a beneficial effect on the development of thinking, imagination, memory, attention, perception, thanks to which the child will learn more successfully. Creative activity makes the child's life more interesting, richer, fills it with vivid impressions.
The main thing in creativity is freedom of activity, and where, if not in art classes, you can afford to express your imagination. The visual activity offers tremendous opportunities to use the rich material for creativity. The more varied and unusual material a student has for obtaining an image, the brighter his imagination will manifest, and the more original the creative product will be. In his works, the student reflects his emotions, thoughts, ideas, conveys images in his own way. Visual activity is one of the most favorite activities of children. In a pictorial form, children freely convey a timely internal vision of the world around them.

Children are inexhaustible in their need to put their impressions on paper. They turn to the pictorial image as a visual, living form of expression of impressions and feelings. Like play, painting is a powerful way to explore the world and art. While the child is drawing, he thinks about the subject of his image as if he were talking about it. In the character of a child who regularly draws, such manifestations as: attention, thoroughness, patience, planning of the work process are gradually and naturally brought up.

Creative ways of portraying contribute to growing up, because they allow without fear, without fear of consequences, to try and take risks, exploring their own possibilities, knowing themselves. In addition, children develop the ability to cope with feelings and experiences. A novelty of discoveries - unusual forms of the image, can become the key that unlocks the doors to the world of joy, inspiration, pleasure.

The visual activity of schoolchildren contributes to the simultaneous development of abstract thinking and concrete, sensory experiences in them. In the process of the image, the child selects from the integral visual image proportions, color, silhouette, line as general and constant characteristics of the visual perceived 
CURRENT RESEARCH JOURNAL OF PHILOLOGICAL SCIENCES 2(5): 55-61,

May 2021 DOI: https://doi.org/10.37547/philological-crjps-02-05-14

ISSN 2767-3758

(C)2021 Master Journals

\section{Crossref do) 81 Google}

Accepted25 $5^{\text {th }}$ May, 2021 \& Published 31 $1^{\text {th }}$ May, 2021

by him reality and as coordinates for comparing specific objects with their image.

For the successful organization of classes in the visual arts, it is necessary to create certain pedagogical conditions:

1. Development of interest in the study of fine arts. This condition is necessary for the manifestation of artistic creativity.

Methods of artistic pedagogy such as:

? method of stimulating imaginative thinking: it is necessary that the moment of entering the concept of future work is more emotional for the student (use of artistic words, music, visuals), it is important that students can immerse themselves in their thoughts;

2] the method of freedom in the system of restrictions: allows you to develop your imagination when creating a composition by restricting, for example, colors (for example, the task: to come up with and draw an illustration of the hot summer of Uzbekistan in a warm scale).

2. Consistent complication of visual activity. On the basis of this condition, programs on the fine arts and methodological recommendations to them have been created. The complication of the material occurs taking into account the agerelated capabilities of children. In the lesson, artistic activity also becomes more complicated, from simple to complex.

3. Teaching the "language" of fine arts and means of artistic expression. This work is carried out in stages: from teaching the ability to analyze, to the formation of the ability to apply (format, rational placement on a sheet, highlighting the compositional center, ways of transferring space, point of view in composition ...).

4. Introduction to the structure of classes in the fine arts of individual game elements and elements of competition.
5. Purposeful, systematic use of art history stories and conversations. This activates the child's attention, the work of thoughts, emotional and aesthetic responsiveness, fantasy, creativity, tunes in to work. The conversation, as a rule, is accompanied by the demonstration of a variety of visual materials (reproductions, postcards, illustrations).

The conversation will help to activate the thoughts of children, their fantasies, emotional mood, and, as a result, the harmonious performance of work in color.

6. The use of a variety of artistic materials and techniques, including non-traditional image techniques. The use of materials such as pencil, watercolor, crayons, black ink, gouache, colored or tinted paper-different formats help to develop the imagination. At the same time, learning how to work with them is just as important, since the focus should be on mastering the artistic image.

After all, it has long been known how great the significance of color is in human life. Life is full when it is filled with colors, colors and shades. Since ancient times, color has been a strong, but still elusive force that determines human behavior.

It is difficult to argue what power such a familiar component of our life as color has over us. A large amount of research has been carried out, and yet color is still a mysterious phenomenon. And the riddle of color has not yet been solved why and how exactly does it affect the mood and behavior of a person.

Color is light. This conclusion was reached by the English physicist and mathematician Isaac Newton while conducting experiments on the study of the color spectrum. It is being at home in a dark room, opened the window and let in a small strip of light. By placing a glass prism along the path of a ray of light, he found that the light refracted and split into six colors of the 
CURRENT RESEARCH JOURNAL OF PHILOLOGICAL SCIENCES 2(5): 55-61,

May 2021 DOI: https://doi.org/10.37547/philological-crjps-02-05-14

ISSN 2767-3758

(C)2021 Master Journals

\section{Crossref do) 81 Google}

Accepted25 $5^{\text {th }}$ May, 2021 \& Published 31 $1^{\text {th }}$ May, 2021

spectrum, which became visible when it hit an adjacent wall.

Several years later, another English physicist, Thomas Jung, conducted a reverse experiment and found that the six colors of the spectrum can be reduced to three main ones: green, red and blue. Then he took three lamps and projected beams of light through filters of these three colors: green, red and blue beams combined into one white beam. Jung recreated the light. It also classified the colors of the spectrum as primary and secondary.

Thus, physicists give the following definition of color: "Color is a qualitative characteristic of electromagnetic radiation in the optical range, determined on the basis of the arising physiological visual sensation of color".

Color is the subjective perception of visible light by the human brain, differences in its spectral structure, as perceived by the eye. Light affects the photosensitive receptors of the retina, which then generate a signal that is transmitted to the brain. It turns out that the perception of color is formed in a complex way in the chain: the eyes (neural networks of the retina and exteroreceptors) - visual images of the brain.

Thus, color is an interpretation of the surrounding world in the mind of a person, resulting from the processing of signals coming from the light-sensitive cells of the eye - cones and rods. In this case, the former are responsible for the perception of color, and the latter are responsible for the acuity of twilight vision.

The eye responds to three primary tones: blue, green, and red. And the brain perceives colors as a combination of these three basic colors.

Scientists in different fields of science called color differently, highlighting the psychological and physiological components of the effect of color. And these components are related to emotions, mood, feelings - to the manifestations of the human soul.

A person has the ability to see the world around him in all the variety of colors and shades. He can admire the sunset, emerald greens, bottomless blue skies and other beauties of nature.

Therefore, one of the bright and often defining features of objects and phenomena is color. Colors have properties to affect people in different ways, to evoke a wide variety of emotions and feelings. For a long time, color has been considered one of the important properties and phenomena of the surrounding life. Already in the ancient world, people noticed that color can not only please a person, but also cause anxiety, irritation, feelings of sadness or longing. Some colors calm the nervous system, while others, on the contrary, irritate. In other words, color has an emotional impact on us.

\section{Conclusion}

The perception of color largely depends on the personal characteristics of a person. This fact was proved in his works on the individual perception of color compositions by the German psychologist M. Luscher. According to his theory, a person in a different emotional state can react differently to the same color. The peculiarities of color perception, the psychologist says, depend on the degree of personality development, but even with a weak susceptibility, the colors of the surrounding world are perceived ambiguously. Warm and light tones attract the eye more than dark ones, but at the same time, toxic colors cause anxiety, and a person's vision begins to involuntarily look for a cold green or blue hue to calm down.

Based on the foregoing, we can draw the following conclusions that creative imagination is one of the types of imagination that allows a person to independently create new ideas that are of certain value to other people or society as a whole and are embodied in specific products of 
CURRENT RESEARCH JOURNAL OF PHILOLOGICAL SCIENCES 2(5): 55-61,

May 2021 DOI: https://doi.org/10.37547/philological-crjps-02-05-14

ISSN 2767-3758

(C)2021 Master Journals

\section{Crossref do) 81 Google}

Accepted25 th May, 2021 \& Published 31 ${ }^{\text {th }}$ May, 2021

activity. Creative imagination is the basis of human creative activity. As a necessary element of any creative activity, imagination plays a special role in the life of a child of middle school age.

\section{REFERENCES}

1. Байметов, Б. Б. (2016). История развития изобразительного искусства Узбекистана. Наука, образование и культура, (1 (4)).

2. Baymetov, B. B., \& Sharipjonov, M. S. 0. (2020). Development Of Students' Descriptive Competencies In Pencil Drawing Practice. The American Journal of Social Science and Education Innovations, 2(08), 261-267.

3. Boltabayevich, B. B., \& Shodievna, B. 0. (2020). Individual Approach To The Formation Of Artistic And Creative Talents Of Students In Art Schools. The American Journal of Social Science and Education Innovations, 2(08), 637-642.

4. Boltabayevich, B. B, \& Pardaboy, K. (2020). Scientific and theoretical aspects of the formation of compositional abilities of students in painting classes. European Journal of Research and Reflection in Educational Sciences Vol, 8(3).

5. Байметов Ботир Болтабаевич. Актуальные вопросы подготовки педагогических кадров республике Узбекистан. Международный научный журнал «ВЕСТНИК НАУКИ» 2020/10. Том 1. 10 (31). Страницы 5-9.

6. 6. Байметов Ботир Болтабоевич. Тасвирий санъатдан бўлажак рассомўқитувчиларни касбий тайёрлашда композиция фанининг назарияси ва методикаси. Science and education journal. 2020/4. Стр. 461-467
7. Байметов, Б. Б. (2020). Педагогика олий таълим муассасаларида талабаларга композиция фанини ўқитишнинг назарияси ва амалиёти. Science and Education, 1(7).

8. Байметов, Б. Б., Султанов, Х. Э., \& Муратов, Х. Х. (2019). Психологические основы активизации творческих способностей студентов в процессе практических занятий. Вестник науки, 1(7), 67-71.

9. Байметов, Б. Б., \& Талипов, Н. Х. (2016). Методическая последовательность ведения работы над живописным портретом в педагогическом ВУЗЕ. Научная дискуссия: вопросы педагогики и психологии, (4-1), 46-50.

10. Baymetov, B. B. (2020). Development of The Ability To See And Represent The Form Remotely In The Process Of Teaching Students To Portray A Creature In Higher Pedagogical Education. The American Journal of Applied sciences, 2(10), 154159.

11. Botir Boltabaevich Baymetov. Development of The Ability To See And Represent The Form Remotely In The Process Of Teaching Students To Portray A Creature In Higher Pedagogical Education. 2020/10Журнал. The USA Journals. Том2. Страницы- 154-159

12. Botir Boltabayevich Baymetov. Technologies Of Moving Images Of People From Different Views In Fine Arts Lessons. The American Journal of Social Science and Education Innovations. The American Journal of Social Science and Education Innovations (ISSN - 2689-100x) Published: January 31, 2021. Стр. 463-468

13. BB Baymetov. Inson qomatining turli ko'rinish va holatlaridan qisqa muddatli 
CURRENT RESEARCH JOURNAL OF PHILOLOGICAL SCIENCES 2(5): 55-61,

May 2021 DOI: https://doi.org/10.37547/philological-crjps-02-05-14

ISSN 2767-3758

(C)2021 Master Journals

\section{Crossref do) 81 Google}

Accepted25 th May, 2021 \& Published 31 ${ }^{\text {th }}$ May, 2021

tasvirlaridan bajarish myetodikasi.

"Science and Education" Scientific Journal January 2021 / Volume 2 Issue. 357-365

14. Botir Boltabaevich Baymetov. oliy pyedagogik ta'limda bo'lajak tasviriy san'at o'qituvchilarining ijodiy qobiliyatlarini shakllantirishning ba'zi masalalari. academic research in educational sciences volume 2 | issue 1 | 2021. 277-283 бетлар.

15. BB Baymetov, $\mathrm{XX}$ Muratov.Tasviriy san'atdan amaliy mashg'ulotlarida talabalarning tasvirlash mahoratlarini takomillashtirish texnologiyalari.Science and Education, 2021.349-354.

16. Мукаддам Тожикузи кизи Хамрокулова, Рашид Неъматович Зульфиев, Ботир Болтабаевич Байметов. Теория и практика преподавания академического рисунка в подготовке будущего художника педагога. Science and education scientific journal. 2020/12.Том 1. Номер 9. стр 364-372.

17. Botir Boltabaevich Baymetov. Art of Modern Uzbekistan: The History Of Its Development During The Years of Independence. The American Journal of Social Science and Education Innovations. 2020/10. 125-132.

18. BB Boltaboevich. Methods of portraiture in the process of making sketches and drawings of the human face in higher pedagogical education. International Journal of Psychosocial Rehabilitation, 2020. Том24. Номер5.Страницы64086415.

19. Botir Boltabayevich Baymetov. Technologies Of Moving Images Of People From Different Views In Fine Arts Lessons. The American Journal of Social Science and Education Innovations. 2021/1. The American Journal of Social Science and
Education Innovations (ISSN - 2689-100x) Published: January 31, 2021.том 3.номер 1. Страницы 463-468.

20. BB Baymetov.Inson qomatining turli ko'rinish va holatlaridan qisqa muddatli tasvirlaridan bajarish myetodikasi"Science and Education"Scientific. January 2021.Volume 2Issue1.357-365.

21. BB Baymetov, $X X$ Muratov. Tasviriy san'atdan amaliy mashg'ulotlarida talabalarning tasvirlash mahoratlarini takomillashtirish texnologiyalari. Science and Education, 2021. 349-356.

22. Botir Boltabaevich Baymetov Xusan Xolmuratovich Muratov. Methods of Teaching Students To Do Sketches In Independent Learning.2020/12. The American Journal of Social Science and Education Innovations. 2. Номер 12. Страницы 8-13

23. Ulfat Shuxratovich Ismatov Botir Boltabaevich Baymetov. Pedagogika oliy ta'lim muassasalarida talabalarini bosh namunasini tasvirlashga o'rgatish orqali tyexnik mahoratlarini takomillashtirish. 2020/11. "Science and Education" Scientific Journal November 2020 /Volume 1 Issue 8 Страницы476-484

24. Laylo Mirsoatova Botir Boltabayevich Baymetov. Oliy pyedagogik ta'limda inson qomatini tasvirlashning nazariyasi va myetodikasi.2020/11 "Science and Education" Scientific Journal November 2020 / Volume 1 Issue 8. Страницы467475

25. Botir Boltabaevich Baymetov, Ulfat Shuhratovich Ismatov. Development of competencies of future fine art teachers in description of nature in graphic materials. 2020. ACADEMICIA: An International Multidisciplinary Research Journal.том 
CURRENT RESEARCH JOURNAL OF PHILOLOGICAL SCIENCES 2(5): 55-61,

May 2021 DOI: https://doi.org/10.37547/philological-crjps-02-05-14

ISSN 2767-3758

(C)2021 Master Journals

Crossref do: 81 Google

Accepted25 $5^{\text {th }}$ May, 2021 \& Published 31 ${ }^{\text {th }}$ May, 2021

10.Номер11.Страницы864-871.

26. Botir Boltabaevich Baymetov. Creativity of The Outstanding Artist-Miniaturist Kamaleddin Behzad (1455-1536). INTERNATIONAL SCIENTIFIC AND CURRENT RESEARCH CONFERENCES "SCIENCE AND INNOVATION IN THE XXI CENTURY: CRUCIAL ISSUES, DISCOVERIES AND ACHIEVEMENTS" Doi https://doi.org/10.37547/iscrc-intconf03 2021/2/19.Pages: 67-71. Hungary, Europe.

27. Shoxidahon Odiljonovna Botirova Boltabaevich Baymetov. Theoretical foundations of coloring in the organization of fine arts classes.2021/4. ACADEMICIA: An International Multidisciplinary Research Journal https://saarj.com.Том11,номер4,Страниц ы775-782.

28. Bobur Abdugani Ogli Nabiyev Botir Boltabayevich Baimetov. Technologies for Improving the Composition of Students in the System of Higher Pedagogical Education2021/4. The American Journal of Social Science and Education Innovations.Hoмер03. Страницы64-70

29. Pardaboy Khudoyberdiev Baimetov Botir Boltabayevich Use The Theoretical Foundations Of Color Science In Teaching Students To Work With Educational Productions From Painting.2021/3. The American Journal of Social Science and Education Innovations. Номер 03.Страницы 330-337.

30. Muxiddin Sharipjonov Botir Baymetov. Oliy pedagogik ta'limda talabalarga inson qiyofasini amaliy tasvirlash jarayonida ijodiy kompyetyensiyalarini rivojlantirish. 2021. ACADEMIC RESEARCH IN EDUCATIONAL SCIENCES. Tом 2.Номер 3.1066-1070.
31. Iqboloy Ibrahimova Botir Boltabaevich Baymetov. Technologies for using fine arts in developing students' artistic imagination. 2021/4. Asian Journal of Multidimensional. Research (AJMR) https://www.tarj.in.Том10.4. 544-551.

32. Указ Президента Республики Узбекистан “О стратегии действий по дальнейшему развитию Республики Узбекистан" от 7 февраля 2017 года УП4947. - Собрание законодательства Республики Узбекистан, 2017 г., №6, ст.70. 